University of Nebraska - Lincoln

DigitalCommons@University of Nebraska - Lincoln

\title{
Assemblages of breeding birds as indicators of grassland condition
}

Sharon Freshman Browder

U.S. Fish and Wildlife Sewice

Douglas H. Johnson

USGS Northern Prairie Wildlife Research Center, Douglas_H_Johnson@usgs.gov

I. J. Ball

University of Montana

Follow this and additional works at: https://digitalcommons.unl.edu/usgsnpwrc

Part of the Other International and Area Studies Commons

Browder, Sharon Freshman; Johnson, Douglas H.; and Ball, I. J., "Assemblages of breeding birds as indicators of grassland condition" (2002). USGS Northern Prairie Wildlife Research Center. 201.

https://digitalcommons.unl.edu/usgsnpwrc/201

This Article is brought to you for free and open access by the US Geological Survey at DigitalCommons@University of Nebraska - Lincoln. It has been accepted for inclusion in USGS Northern Prairie Wildlife Research Center by an authorized administrator of DigitalCommons@University of Nebraska - Lincoln. 


\title{
Assemblages of breeding birds as indicators of grassland condition
}

\author{
Sharon Freshman Browder ${ }^{a, *}$, Douglas H. Johnson ${ }^{b}$, I.J. Ball ${ }^{\mathrm{c}}$ \\ ${ }^{a}$ U.S. Fish and Wildife Service, P.O. Box 247, Stevensville, MT 59870, USA \\ ${ }^{\mathrm{b}}$ Northern Prairie Wildlife Research Center, U.S. Geological Survey, 8711 37th Street SE, Jamestown, ND 58401, USA \\ ${ }^{\mathrm{c}}$ Montana Cooperative Wildlife Research Unit, U.S. Geological Survey, University of Montana, Missoula, MT 59812, USA
}

\begin{abstract}
We developed a measure of biological integrity for grasslands (GI) based on the most influential habitat types in the Prairie Pothole Region of North Dakota. GI is based on proportions of habitat types and the relationships of these habitat types to breeding birds. Habitat types were identified by digital aerial photography, verified on the ground, and quantified using GIS. We then developed an index to GI based on the presence or abundance of breeding bird species. Species abundance data were obtained from $3 \mathrm{~min}$ roadside point counts at 889 points in 44,4050 ha study plots over a 2 -year period. Using a modified North American Breeding Bird Survey protocol, species were recorded in each of four quadrants at each point. Fifty species selected for analysis included all grassland species that occurred in at least 15 quadrants and all other bird species that occurred in at least $1 \%$ of quadrants. We constructed preliminary models using data from each of the 2 years, then tested their predictive ability by cross-validation with data from the other year. These cross-validation tests indicated that the index consistently predicted grassland integrity. The final four models (presence and abundance models at 200 and $400 \mathrm{~m}$ scales) included only those species that were statistically significant $(P \leq 0.05)$ in all preliminary models. Finally, we interpreted the components of the indices by examining associations between individual species and habitat types. Logistic regression identified 386 statistically significant relationships between species and habitat types at 200 and $400 \mathrm{~m}$ scales. This method, though labor-intensive, successfully uses the presence of grassland-dependent species and absence of species associated with woody vegetation or cropland to provide an index to grassland integrity. Once regional associations of species with habitat types have been identified, such indices can be applied relatively inexpensively to monitor grassland integrity over large geographic areas. Indices like the ones presented here could be applied widely using bird abundance data that are currently being collected across the United States and southern Canada through the North American Breeding Bird Survey.
\end{abstract} (C) 2002 Elsevier Science Ltd. All rights reserved.

Key phrases: Assemblages of grassland birds; Biological integrity; Birds as indicators of grassland integrity; Index of grassland integrity; Indicators of environmental condition; Presence and abundance of grassland birds

Keywords: Grassland birds; North Dakota; Northern Great Plains; Point counts; Prairie Pothole Region

\section{Introduction}

Declines in populations of many species of grass-

* Corresponding author. Tel.: +1-406-777-1576; fax: +1-406-777-1576.

E-mail address: sharon_browder@fws.gov (S.F. Browder). land birds in North America have been more precipitous than those of birds in forests and other biomes (Robbins et al., 1986; Drocge and Saner, 1994; Knopf,

1470-160X/02/\$ - see front matter (C) 2002 Elsevier Science Ltd. All rights reserved. PII: S1470-160X(02)00060-2

This article is a U.S. government work, and is not subject to copyright in the United States. 
1994; Vickery et al., 1999). Many species nesting in grasslands and scrublands showed consistent population declines between 1966 and 1991 (Peterjohn and Saber, 1993). Most North American grassland species both breed and winter on this continent (Igl and Johnson, 1997), so these declines must be a function of processes occurring primarily in North America (Kaopf, 1994).

Declines in grassland birds have been attributed to extensive and continuing conversion of grasslands to cropland and to increasingly intensive agricultural practices (Herkert, 1994; Bollinger and Gavin, 1992). Native grasslands have been altered to a greater degree than any other biome in North America, including forests (Samson and Knopf, 1994; Noss et al., 1995). Most grassland losses have resulted from tillage for croplands: in North Dakota, nearly $70 \%$ of the total land area has been tilled. Most of the remaining grasslands, approximately $26 \%$ of North Dakota's total land area, are pastureland and rangeland (US Deparment of Commerce, 1994). Grassland conversion also has been accompanied by destruction of wetlands (Dahl et al., 1991), negatively affecting grassland species associated with wetlands (Johnson, 1996). Additionally, widespread planting of trees in the Great Plains (Bacr, 1989) has changed avian species composition by creating suitable habitats for woodland and edge species (Martin and Vohs, 1978; Martin, 1980; Igl and Johnson, 1997).

Wide-scale grassland conversion is detrimental to grassland birds for several reasons. Most grassland conversions permanently eliminate the vegetation on which many grassland species depend for breeding-habitat. Although croplands provide habitat for some species, the value of cropland as breeding-habitat is limited because of the disturbance that occurs several times each year as fields are tilled, planted, sprayed, and harvested. The value of croplands is further limited by the simple structure of the vegetation, which differs markedly from intact grasslands. Few converted grasslands are maintained in perennial grass cover, and then only if they are used as pasture or hayland or are enrolled in an agricultural subsidy program, such as the Conservation Reserve Program (CRP). Often only small patches of native grassland remain in agricultural landscapes, and such remnant grasslands usually are hayed or heavily grazed (Stewart, 1975). Recently, conversion of hay- fields from grass to alfalfa, earlier hay-cropping dates, and earlier rotation of hayfields to other crops may have contributed to declines of some grassland birds (Bollinger and Gavin, 1992). Heavily grazed grasslands support fewer avian species than those that are lightly or moderately grazed (Kantrud, 1981). Small patches of grassland often are more attractive to edge species than to grassland species, and some species of grassland birds do not breed in small patches of grassland (Herkert, 1994). Other species suffer relatively high rates of nest predation and brood parasitism by Brown-headed Cowbirds (Molothrus ater) in small tracts (Johnson and Temple, 1990; Camp and Best, 1994).

Growing concern about the effects of wide-scale anthropogenic changes to grasslands and other ecosystems has created a need for monitoring methods that can detect changes in biological integrity over large geographic areas. Here we use Karr's (1991) definition of biological integrity "... the ability to support and maintain a balanced, integrated, adaptive community of organisms having a species composition, diversity, and functional organization comparable to that of natural habitat of the region." Monitoring methods that reflect changes in biological integrity have been developed for fish (Karr, 1981, 1991; Karr et al., 1986), butterflies (Noss, 1990; Kremen, 1992; Blair and Launer, 1997), aquatic invertebrates (Berkman et al, 1986; Lenat, 1988; Ohio EPA, 1988; Plafkin et al., 1989), and shrub-steppe birds (Bradford et al., 1998). To date, methods widely used to evaluate grassland health have focused on the quantity of forage produced or the abundance and density of plant species over a relatively small area, rather than on the organisms that a grassland supports over a large geographic area (US Department of Agricuhure, 1997). We surmised that grassland birds may provide a useful index of biological integrity in grassland ecosystems.

Bird taxa are appropriate indicators for monitoring changes on an ecosystem scale for several reasons: (1) individual bird species are associated with particular habitats; (2) birds occur across a broad gradient of anthropogenic disturbance, from pristine wilderness to metropolitan areas; (3) most birds live only a few years, so changes in species composition and abundance will manifest relatively quickly after a disturbance; (4) systematic and extensive bird surveys (e.g. Breeding Bird Survey, Robbins et al., 1986) are 
currently conducted across the United States and southern Canada; (5) groups of bird species can be used to develop associations with habitats that are predictive of the relative level of anthropogenic disturbance (\$zaro, 1986, Croonquist and Brooks, 1991; Bradford at al, 1998, Canterbury et al., 2000); (6) birds are important to a large segment of the public, so the public may better relate to concerns about changes in bird communities than to those of other taxa, such as plants or invertebrates.

We developed a measure of grassland integrity based on the most important habitat types in the Prairie Pothole Region of North Dakota. We then developed indices, consisting of four linear regression models, that predict grassland integrity using presence or abundance of disturbance-intolerant and disturbance-tolerant bird species. The indices provide a method of monitoring grassland integrity based on the tolerance of grassland birds to anthropogenic disturbance, particularly cultivation.

\section{Methods}

\subsection{Study area}

Study plots were located in the 11.7 million hectare portion of North Dakota lying east and north of the Missouri River (Fig. 1), commonly referred to as the Prairie Pothole Region. Glaciation during the Wisconsin Age formed gently rolling to nearly flat terrain interspersed with millions of wetland basins, or Prairie Potholes. Elevations across the study area range from about $240 \mathrm{~m}$ at the Minnesota border to about $730 \mathrm{~m}$ above mean sea level near the Montana border. The proportion of land under cultivation

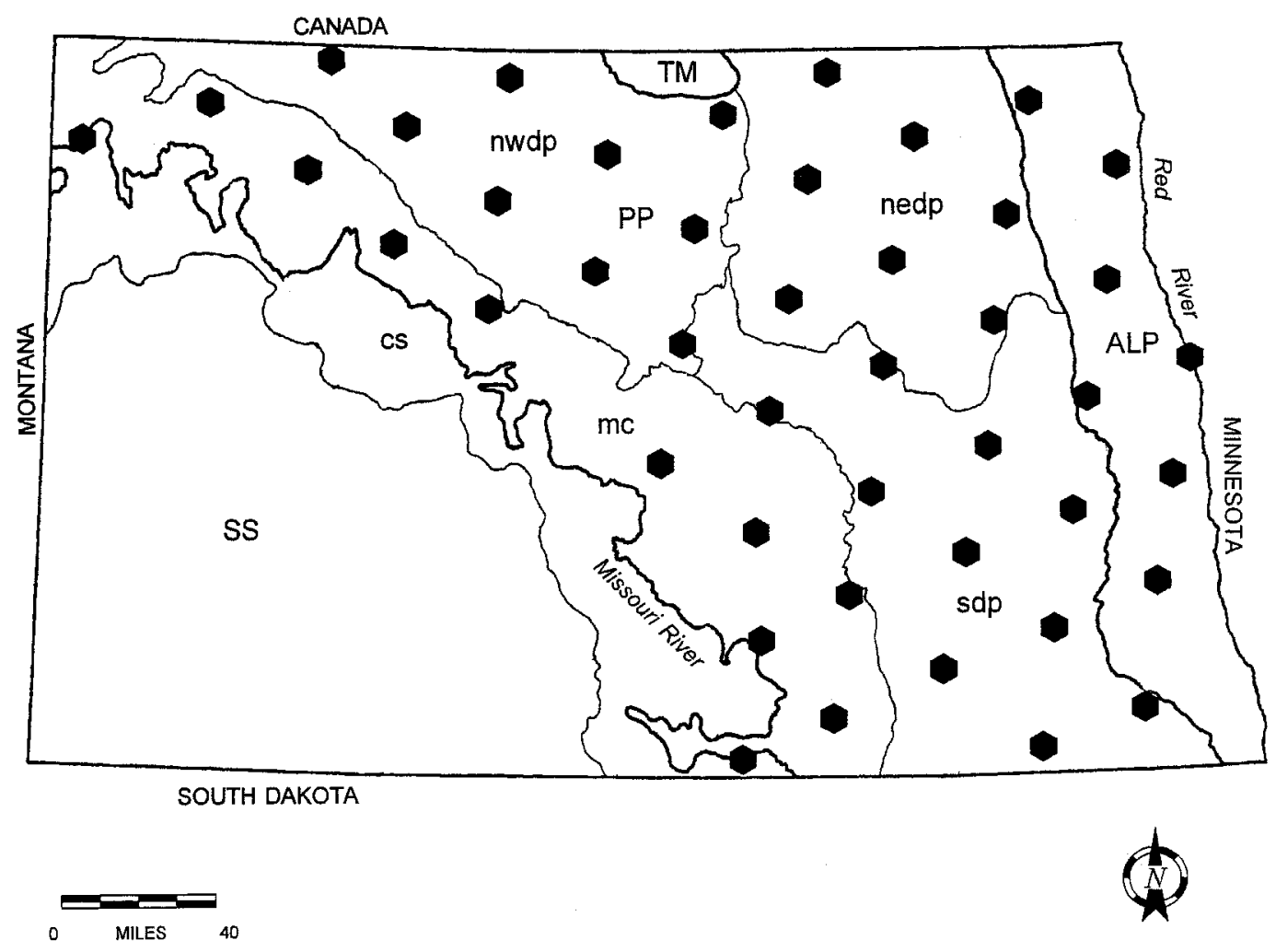

Fig. 1. Study area, locations of hexagons, and biotic regions of North Dakota (Stewart, 1975). Physiographic regions delineated by thicker line (a): ALP, Aggasiz Lake Plain; PP, Prairie Pothole; SS, Southwestern Slope; TM, Turtle Mountain. Biotic subregions delineated by thinner line (-): cs, Couteau Slope; mc, Missouri Couteau; nedp, Northeastern Drift Plain; nwdp, Northwestern Drift Plain; sdp, Southern Drift Plain. (Hexagon location. 
increases in a rough gradient from west to east, as does average precipitation. Many of the most pristine grasslands that remain in the study area are found in the Missouri Couteau, where the rolling terrain contains areas of pasture and CRP and many natural wetlands. Grasslands contain a mixture of native species, such as Prairie junegrass (Koeleria pyramidata), needle-and-thread (Stipa comata), blue grama (Bouteloua gracilis), little bluestem (Schizachyrium scoparium), western wheatgrass (Agropyron smithii), threadleaf sedge (Carex filifolia), as well as invasive species, such as smooth brome (Bromus inermis) and Kentucky bluegrass (Poa pratensis). Low shrubs, such as snowberry (Symphoricarpos occidentalis) and silverberry (Eleagnus commutata) are common. Pasture and CRP are often composed of smooth brome and alfalfa (Medicago sativa) cultivars. Crops in the Missouri Couteau are predominantly small grains. In contrast, the flat Agassiz Lake Plain Region along the Red River in eastern North Dakota contains the most altered landscape in the study area. The region is heavily cultivated, and few natural wetlands or grasslands remain. Many fields have been leveled, ditched, and tile-drained and often are planted to intensively managed crops, such as sugar beets, soybeans, sunflowers, or canola. Conditions on the Drift Plain are intermediate between the Missouri Couteau and the Agassiz Lake Plain. Topography is rolling to flat. A large proportion of the Drift Plain is tilled, yet natural wetlands and some areas of native vegetation remain.

Following the sampling scheme designed for EMAP (US Environmental Protection Agency, 1993), we obtained a systematic sample of 44 hexagons (mean hexagon size was 4049 ha, range $=3939-4135$ ha) distributed across the study area. Of the 44 hexagons, 9 occurred in the Missouri Couteau, 8 in the Northwestern Drift Plain, 7 in the Northeastern Drift Plain, 11 in the Southern Drift Plain, and 7 in the Agassiz Lake Plain. Two hexagons overlapped the Missouri Couteau and Couteau Slope.

\subsection{Species composition and relative abundance}

We surveyed breeding birds inside the hexagons using roadside point counts. Our survey method was modified from the North American Breeding Bird Survey protocol (Robbins et al., 1986) to conform to the road length and configuration in the hexagons and to facilitate analysis of bird associations with habitat types. A standard Breeding Bird Survey route consists of 50 points, $0.8 \mathrm{~km}$ apart, and data are collected along the route one morning of the year during the peak of the breeding season. Starting $0.5 \mathrm{~h}$ before sunrise, an observer records all birds heard or seen within $400 \mathrm{~m}$ during a 3 min period at each point. Our surveys incorporated the following modifications: (1) survey routes were shortened so they could be accommodated inside the hexagons, (2) birds were recorded separately by quadrant (NE, SE, SW, NW) at each point, and (3) birds observed in quadrants were recorded in separate categories from those flying overhead or observed on the road surface; data from the latter category were not used in this analysis. Roads in North Dakota generally follow a north-south or east-west configuration in a grid pattern.

Bird surveys began along the southwest edge of the study area (Fig. 1) and proceeded to the northeast, following the general sequence of breeding phenology in North Dakota (Stewart, 1975). Surveys were conducted from late May through early July in 1995 and 1996. We recorded data in 44 hexagons in 1995 and 43 in 1996 (data were not collected in one hexagon in 1996 due to inclement weather). Hexagons contained an average of $15.3 \mathrm{~km}$ of survey route and 20 survey points. High water caused some points to become inaccessible: in 1996, 17 points were deleted and 3 were added. We used a Global Positioning System unit to determine the coordinates of each survey point.

\subsection{Habitat types}

Digital aerial photography recorded habitat types at regular intervals on all 44 hexagons between May and August of 1995 and 1996. Aerial photographs were interpreted in a Geographic Information System (MicroImages TNTMIPS software; Microlmages, 1996) to delineate habitat types. Because changes in habitat type were minimal between the two study years, data were combined to create a single base map. The predominant habitat types in each quadrant were ground truthed. Twenty-two habitat types delineated through photo-interpretation were collapsed into seven categories: Cropland, Grassland, Wetland, Patch, Wood, Other, and Barren Land.

Cropland includes lands that were tilled and planted to small grain or row crops, and includes freshly tilled 
soil, stubble from the previous year, fallow land, and growing crops. Grassland includes native grassland tracts $>2$ ha. Hayland and CRP also were included in this category because both provide habitat that is structurally similar to native grassland (Johnson and Schwartz, 1993a). Haylands are composed of grass or legumes that are cut at least once annually for livestock forage, and CRP lands are planted to perennial cover in the form of grass or a mixture of grass and legumes. Wetland includes all wetland types present (Cowardin et al. 1979). Patch includes areas $<2$ ha that contain $<50 \%$ woody vegetation as well as linear habitats (3-20 $\mathrm{m}$ wide) between fields, along fences and section lines, and along road and railroad rights-of-way. These areas are unplowed, but sometimes are mowed during the growing season. Vegetation often consists of smooth brome. Wood includes areas $>2$ ha containing woody plants $>6 \mathrm{~m}$ tall with $\geq 30 \%$ aerial cover, areas $<2$ ha containing $>50 \%$ woody plants, shelterbelts (rows of trees planted as windbreaks), and scrub land areas $>2$ ha covered in shrubs $0.9-6 \mathrm{~m}$ tall. Other includes small ( $<2$ ha) areas, such as farmsteads and rock piles, that do not fit in any other class. Barren Land includes highly developed areas, such as road surfaces (dirt, gravel, and paved), parking lots, and buildings (except farmsteads, which are categorized as Other).

The area of each habitat type was determined using the following procedures. Coordinates collected at each survey point using a Global Positioning System were entered into a point file. A buffer zone was created around all points at radii of 200 and $400 \mathrm{~m}$ using TNTMIPS software (Microlmages, 1996). The $200 \mathrm{~m}$ scale was chosen as a reasonable distance within which a stationary observer could identify most passerine birds by sight or sound, and the $400 \mathrm{~m}$ scale was chosen because it is the same as that used by the Breeding Bird Survey (Robbins ef al., 1986). We then manually digitized each buffer zone into quadrants along existing roads and section lines. Quadrants were manually labeled and buffers were merged with the habitat type layer. Features inside the buffers were extracted from the merged layer to obtain only those habitat type polygons within the buffers. Databases were generated containing the area of each habitat type polygon inside the quadrants.

Some $400 \mathrm{~m}$ buffers extended beyond hexagon boundaries, and habitat type composition could not be determined for these quadrants $(n=468$ ). Thus, only 6772 of the original 7240 quadrants were used in the analyses.

We used independent-samples $t$-tests (Norusis, 1995) to compare mean percent of total area for each habitat type in the 200 and $400 \mathrm{~m}$ quadrants with those of the hexagons to determine if the quadrants were representative of the hexagons as a whole. To determine if the distribution of habitat types differed between the 200 and $400 \mathrm{~m}$ scales, we also examined frequency of occurrence of each habitat type in the quadrants analyzed.

\subsection{Predicting grassland integrity}

We developed an a priori measure of grassland integrity (GI) that incorporated the four habitat types that appeared to exert the most influence, either positive or negative, on grassland bird species:

$$
\begin{aligned}
\text { grassland integrity }= & \% \text { grassland }-(\% \text { cropland } \\
& +\% \text { wood }+\% \text { other })
\end{aligned}
$$

The GI is an objective measure of the quality of habitat based on the percentages of the most influential habitat types in a given area. The selection of habitat types for the GI was based on an interpretation of the influence, structure, and function of each habitat type in a grassland ecosystem. Grasslands remaining in an area were considered a positive attribute to grassland integrity regardless of their condition because they provided habitat that is structurally most similar to an intact grassland ecosystem. Cropland was included in the GI as a detractor to grassland integrity because native grassland vegetation is removed and the area is repeatedly disturbed, so birds attracted to cropland will likely suffer high rates of reproductive failure. Other EMAP studies have concluded that cropland areas had negative environmental effects. In areas of the northern plains where corn has replaced native grasslands, concentrations of atrazine in wetland sediments was consistently associated with poor wetland conditions (Larson, 1996). Many seasonal wetlands are tilled in cropland areas during dry periods, and low plant richness and abundance in tilled wetlands consistently indicate poor wetland condition (Kantrud, 1996). Wood and Other also were included in the GI as detractors to grassland integrity because they represent effects 
of anthropogenic changes to the historic structure and integrity of a grassland ecosystem. These effects include increased nest predation and brood parasitism (Johnson and Temple, 1990; Winter et al., 2000) and decreased nest densities (Wiens, 1969; O'Leary, 2000) in grassland-nesting species near woody habitats and edges. The remaining habitat types (Wetland, Patch, and Barren Land) were excluded from the GI because their effects on grassland integrity are mixed or uncertain.

We sought to use bird presence or abundance to predict grassland integrity by developing linear regression models. First, we selected the species to be used in the analysis using the following criteria: grassland species that occurred in at least 15 of the 6772 quadrants and non-grassland species that were observed in at least $1 \%$ of the quadrants (Appendix $A$ ). Total species selected included 11 grassland species and 39 non-grassland species. Because the typical breeding ranges of 18 species did not include all 44 hexagons, we selected hexagons for analysis based on the species' primary ranges (Price et al., 1995), but also included hexagons where we found a species outside its primary range. Many species that occurred in hexagons outside their primary range were wetland and wet-meadow species that likely shifted their distribution and abundance in response to above-normal precipitation and inundation of wetlands between 1993 and 1996 ( $\mathrm{ggl}$ and Johnson, 1999). Using forward stepwise linear regression, we used presence and abundance of the 50 species at two scales (200 or $400 \mathrm{~m}$ ) to build four models predicting grassland integrity: $200 \mathrm{~m}$ presence, $400 \mathrm{~m}$ presence, $200 \mathrm{~m}$ abundance, and $400 \mathrm{~m}$ abundance. Data from two heavily wooded hexagons were not used in the models.

We built preliminary models using data from a single year (either 1995 or 1996). Only those species that were statistically significant in all preliminary models were incorporated into the test models. We then tested the predictive capacity of each of the test models by cross-validation using data from the other year. Predicted index values were calculated for each quadrant by first multiplying the presence ( 1 if present, 0 if absent) or abundance of each species in the model by its regression coefficient and then adding the model intercept. The coefficients of determination $\left(R^{2}\right)$ of each cross-validation test were then compared to those from the original fitting of the test model. Final models were produced by combining data from both years. Similar models and coefficients of determination were obtained by building models using a random sample of two-thirds of the data from both years and cross-validating using the remaining third of the data. For purposes of discussion, significant results, relationships, and differences are those with $P \leq 0.05$.

\subsection{Associations between species presence and habitat type}

To further validate the inclusion of species that occurred in the index, we examined the relationships of species to habitat types. Associations between the presence of each of the 50 species selected and the percentage of each of the seven habitat types in the quadrants were obtained using logistic regression (Norusis, 1995). Species presence was regressed against the percentages of each of seven habitat types at both the 200 and $400 \mathrm{~m}$ scales, resulting in 700 logistic regression coefficients (Browder, 1998).

Associations between bird species and habitat type were measured using the likelihood ( $-2 \log$ likelihood) value of each regression model (Norusis, 1995). A logistic regression model with perfect fit would have a likelihood value of 0 , so we considered those species with a significant $(P \leq 0.05)$ regression coefficient and maximum likelihood to have the strongest relationships.

To examine the relationships between groups of species and habitat types, we categorized the 50 species into seven breeding-habitat groups (Appendix A). Habitat groups included Grassland, Wetland, BareGround, Savanna, Edge, Woodland, and Generalist. We then examined the proportions of each group associated with the habitat types.

\section{Results}

\subsection{Species composition and relative abundance}

During the study, we recorded 130 species, 6 of which were recorded in 1995 but not in 1996 and 10 of which were recorded in 1996 but not in 1995 (Browder, 1998: Appendix E). We recorded 14,399 individuals of 117 species at 894 points in 1995 and 14,330 individuals of 123 species at 868 points in 
Table 1

Percent of total area for each habitat type at three scales on hexagons in the Prairie Pothole Region of North Dakota

\begin{tabular}{|c|c|c|c|c|c|c|c|c|}
\hline \multirow[t]{2}{*}{ Habitat type } & \multicolumn{2}{|c|}{ Hexagon $^{\mathrm{a}}(n=44)$} & \multicolumn{3}{|c|}{$400 \mathrm{~m}$ Quadrant $(n=3620)^{b}$} & \multicolumn{3}{|c|}{$200 \mathrm{~m}$ Quadrant $(n=3620)^{\mathrm{b}}$} \\
\hline & $\bar{x}$ & $95 \% \mathrm{CI}$ & $\bar{x}$ & $95 \% \mathrm{CI}$ & $P^{c}$ & $\bar{x}$ & $95 \% \mathrm{CI}$ & $P^{c}$ \\
\hline Cropland & 62.1 & $56.2,68.0$ & 61.5 & $60.3,62.6$ & 0.830 & 57.3 & $56.2,58.5$ & 0.115 \\
\hline Grassland & 19.4 & $14.6,24.2$ & 16.1 & $15.1,17.1$ & 0.185 & 15.4 & $14.5,16.4$ & 0.114 \\
\hline Wetland & 8.8 & $7.3,0.4$ & 8.8 & $8.4,9.2$ & 0.999 & 8.2 & $7.7,8.7$ & 0.442 \\
\hline Patch & 4.5 & $3.9,5.0$ & 7.3 & $7.0,7.6$ & 0.005 & 10.6 & $10.2,10.9$ & 0.005 \\
\hline Wood & 3.3 & $0.7,5.8$ & 2.6 & $2.2,2.9$ & 0.615 & 2.7 & 2.43 .1 & 0.667 \\
\hline Other & 1.2 & $1.1,1.4$ & 2.0 & $1.8,2.2$ & 0.005 & 2.7 & $2.3,3.1$ & 0.005 \\
\hline Barren Land & 0.8 & $0.7,0.8$ & 1.7 & $1.7,1.8$ & 0.005 & 3.1 & $2.9,3.2$ & 0.005 \\
\hline
\end{tabular}

${ }^{\mathrm{a}}$ Mean hexagon size $=4050 \mathrm{ha}$.

${ }^{\mathrm{b}}$ Analysis included quadrants surveyed in both 1995 and 1996 ( $n=7240$ ). Because some $400 \mathrm{~m}$ buffers extended beyond hexagon boundaries, habitat type composition could not be determined for 468 quadrants. Hence, 6772 of the original 7240 quadrants were used in the analysis.

${ }^{c}$ Significance levels from independent-samples $t$-tests (Norusis, 1995) used to compare the mean percent of total area for each habitat type in 200 and $400 \mathrm{~m}$ quadrants with those of the hexagons.

1996. Averages per hexagon were 40 species and 324 individuals in 1995 and 40 species and 333 individuals in 1996.

\subsection{Habitat types}

Cropland (62.1\%) and Grassland (19.4\%) were the two most common habitat types. Percent composition of most habitat types among hexagons, $400 \mathrm{~m}$ quadrants, and $200 \mathrm{~m}$ quadrants was similar. However, mean percent of total area differed significantly for three habitat types (Table 1). Both 200 and $400 \mathrm{~m}$ quadrants contained higher proportions of Patch, Barren Land, and Other than did hexagons. Distribution of habitat types was similar between the 200 and $400 \mathrm{~m}$ scales for every habitat type except Other, which occurred nearly twice as often in the $400 \mathrm{~m}$ quadrants as in the $200 \mathrm{~m}$ quadrants (Table 2).

The landscape of the entire study area was highly fragmented. However, hexagons varied widely in their degree of fragmentation. A few hexagons contained contiguous grasslands $>16$ ha, but most Grassland fragments were considerably smaller. Because this analysis uses percentages of Grassland that occurred within 200 and $400 \mathrm{~m}$ radii, it is not possible to distinguish the sizes of grasslands sampled by the point counts. However, the frequency with which Grassland and other habitat types occurred in the quadrants (Table 2) may help the reader assess the relative degree of fragmentation.

\subsection{Predicting grassland integrity}

Grassland integrity was predicted by the presence and abundance of 11 species of birds in four linear regression models (Table 3). The models contained nine species with positive coefficients and two with negative coefficients. Coefficients of determination $\left(R^{2}\right)$ were similar for both the initial fitting and for the cross-validation testing. Coefficients of determination $\left(R^{2}\right)$ for the final models also were similar to those in the preliminary models.

\subsection{Associations between species presence and habitat types}

The relationships between species and habitat type supported the occurrence of grassland species in the

Table 2

Frequency and percentage of cover type occurrence at two scales in 6772 quadrants analyzed

\begin{tabular}{lcclll}
\hline Habitat type & \multicolumn{2}{l}{ Frequency } & & \multicolumn{2}{l}{ Percentage } \\
\cline { 2 - 3 } \cline { 6 - 6 } \cline { 6 - 6 } & $200 \mathrm{~m}$ & $400 \mathrm{~m}$ & & $200 \mathrm{~m}$ & $400 \mathrm{~m}$ \\
\hline Cropland & 5536 & 5913 & & 82 & 87 \\
Grassland & 1902 & 2408 & & 28 & 36 \\
Wetland & 4057 & 5342 & & 60 & 79 \\
Patch & 6170 & 6314 & & 91 & 93 \\
Wood & 1108 & 1726 & & 16 & 25 \\
Other & 762 & 1495 & & 11 & 22 \\
Barren Land & 6449 & 6469 & & 95 & 96 \\
\hline
\end{tabular}


Table 3

Intercept term and coefficients of each species in the regression model, as well as various $R^{2}$-values, for linear models that predict grassland integrity from the presence/absence or abundance of species at 200 and $400 \mathrm{~m}$ scales

\begin{tabular}{|c|c|c|c|c|}
\hline \multirow[t]{2}{*}{ Term } & \multicolumn{2}{|c|}{ Species presence } & \multicolumn{2}{|c|}{ Species abundance } \\
\hline & $200 \mathrm{~m}$ & $400 \mathrm{~m}$ & $200 \mathrm{~m}$ & $400 \mathrm{~m}$ \\
\hline Intercept & -57.11 & -59.35 & -52.17 & -57.79 \\
\hline Chestnut-collared Longspur & 87.46 & 85.83 & 48.54 & 41.90 \\
\hline Baird's Sparrow & 60.98 & 72.42 & 58.47 & 69.63 \\
\hline Grasshopper Sparrow & 58.94 & 55.19 & 50.20 & 52.39 \\
\hline Clay-colored Sparrow & 43.35 & 43.18 & 36.68 & 39.77 \\
\hline Amercan Bittern & 28.37 & 31.01 & 28.78 & 26.39 \\
\hline Western Meadowlark & 34.26 & 35.74 & 30.54 & 23.34 \\
\hline Sedge Wren & 32.82 & 33.88 & 26.51 & 28.39 \\
\hline Savannah Sparrow & 20.35 & 17.80 & 17.00 & 11.99 \\
\hline American Coot & 22.04 & 16.41 & 3.37 & 2.38 \\
\hline Vesper Sparrow & -18.13 & -18.37 & -19.41 & -19.44 \\
\hline Horned Lark & -24.48 & -24.16 & -21.42 & -18.74 \\
\hline$R^{2}$ final model & 0.29 & 0.29 & 0.29 & 0.26 \\
\hline$R^{2} 1995$ initial fitting & 0.26 & 0.27 & 0.27 & 0.26 \\
\hline$R^{2} 1995$ cross-validation & 0.28 & 0.28 & 0.23 & 0.25 \\
\hline$R^{2} 1996$ initial fitting & 0.32 & 0.31 & 0.32 & 0.30 \\
\hline$R^{2} 1996$ cross-validation & 0.31 & 0.29 & 0.32 & 0.31 \\
\hline
\end{tabular}

index (Table 4, Browder, 1998: Appendix F). Cropland was negatively associated with all species except Vesper Sparrow (Pooecetes gramineus) and Horned Lark (Eremophila alpestris) (Table 4). In the group analysis, Cropland was negatively associated with the presence of more species $(80 \%)$ than any other habitat type and most (73\%) Grassland species were negatively associated with Cropland (Fig. 2, Browder,
1998: Appendix F). Grassland was positively associated with all upland species in the models except Vesper Sparrow and Horned Lark (Table 4). In the group analysis, Grassland was positively associated with the presence of $40-42 \%$ of all species, and was associated with a higher percentage $(73 \%)$ of Grassland species than any other habitat type (Mig. 2, Browder, 1998: Appendix F). However, in the group analysis, no

Table 4

Associations $\mathrm{s}^{\mathrm{s}}$ of predictive model species with different habitat types at 200 and $400 \mathrm{~m}$ scales determined by logistic regression

\begin{tabular}{|c|c|c|c|c|c|c|c|c|c|c|c|c|c|c|}
\hline \multirow[t]{2}{*}{ Species } & \multicolumn{2}{|c|}{ Cropland $^{b}$} & \multicolumn{2}{|c|}{ Grassland ${ }^{b}$} & \multicolumn{2}{|c|}{ Wetland } & \multicolumn{2}{|l|}{ Patch } & \multicolumn{2}{|l|}{ Wood $^{\text {b }}$} & \multicolumn{2}{|l|}{ Other ${ }^{b}$} & \multicolumn{2}{|c|}{ Barren Land } \\
\hline & $200 \mathrm{~m}$ & $400 \mathrm{~m}$ & $200 \mathrm{~m}$ & $400 \mathrm{~m}$ & $200 \mathrm{~m}$ & $400 \mathrm{~m}$ & $200 \mathrm{~m}$ & $400 \mathrm{~m}$ & $200 \mathrm{~m}$ & $400 \mathrm{~m}$ & $200 \mathrm{~m}$ & $400 \mathrm{~m}$ & $200 \mathrm{~m}$ & $400 \mathrm{~m}$ \\
\hline Chestnut-collared Longspur & - & - & + & + & ns & ns & ns & ns & ns & $\mathrm{ns}$ & $\mathrm{ns}$ & $\mathrm{ns}$ & - & $\mathrm{ns}$ \\
\hline Baird's Sparrow & - & - & + & + & $\mathrm{ns}$ & - & ns & - & $\mathrm{ns}$ & ns & ns & $\mathrm{ns}$ & $\mathrm{ns}$ & $\mathrm{ns}$ \\
\hline Grasshopper Sparrow & - & - & + & + & - & ns & ns & ns & ns & ns & - & ns & ns & $\mathrm{ns}$ \\
\hline Clay-colored Sparrow & - & - & + & + & - & - & + & + & + & + & + & + & + & $\mathrm{ns}$ \\
\hline American Bittern & - & - & ns & + & + & - & + & ns & ns & ns & $\mathrm{ns}$ & ns & ns & ns \\
\hline Western Meadowlark & - & - & + & + & ns & ns & + & + & - & - & - & ns & + & $\mathrm{ns}$ \\
\hline Sedge Wren & - & - & + & + & + & + & + & + & ns & ns & - & - & ns & - \\
\hline Savannah Sparrow & - & - & + & + & $\mathrm{ns}$ & + & + & ns & - & - & - & - & $\mathrm{ns}$ & $\mathrm{ns}$ \\
\hline American Coot & - & - & $\mathrm{ns}$ & ns & + & + & + & + & - & - & - & $\mathrm{ns}$ & $\mathrm{ns}$ & - \\
\hline Vesper Sparrow & + & + & - & - & - & - & - & - & ns & ns & - & - & $\mathrm{ns}$ & $\mathrm{ns}$ \\
\hline Horned Lark & + & + & - & - & - & - & - & - & - & - & - & - & $\mathrm{ns}$ & $\mathrm{ns}$ \\
\hline
\end{tabular}

${ }^{a}(+)$ Positive association $(P \leq 0.05)$; $(-)$ negative association $(P \leq 0.05)$; (ns) not significant $(P>0.05)$.

' The habitat types 'Cropland', 'Grassland', 'Wood', and 'Other' indicate those included in the measure of grassland integrity. 


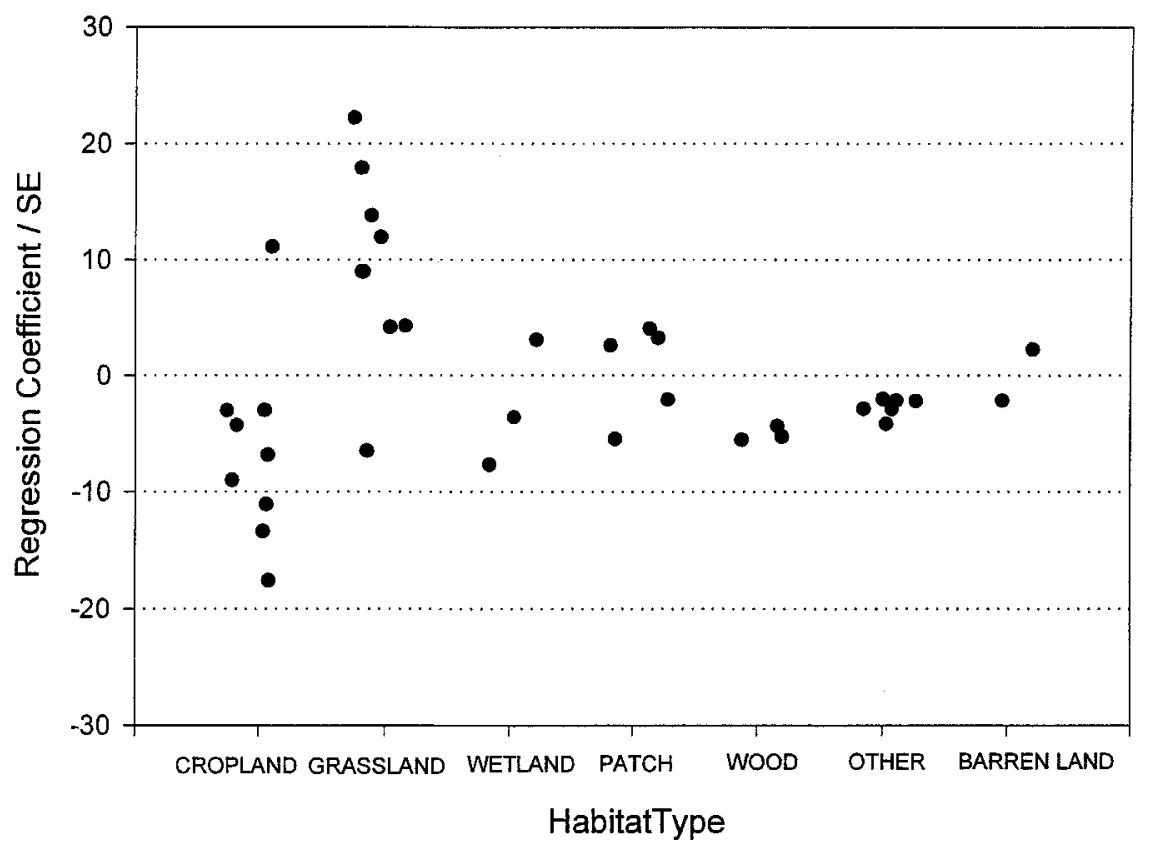

Fig. 2. Significant relationships $(\alpha \leq 0.05)$ of grassland species to habitat type at $200 \mathrm{~m}$ measured by the model regression coefficient divided by the standard error.

Grassland, Wetland, or Bare-Ground species were positively associated with either Wood or Other, but most Edge (69-77\%) and Woodland (100\%) species were positively associated with Wood. In addition, most Edge (85-92\%) and all Savanna, Woodland, and Generalist species were positively associated with Other (Fig. 2, Browder, 1998: Appendix F). A complete listing of the 700 relationships between species presence and habitat type is presented in Browder (1998, Appendix D).

\section{Discussion}

Species that appeared in the models were highly associated with predominant habitat types in the region, particularly Grassland or Cropland, and consistently predicted grassland integrity. Cross-validation of the single-year models produced coefficients of determination $\left(R^{2}\right)$ similar to those of the original fittings, indicating that the models predicted reliably when tested with data collected during a different year. Coefficients of determination in the final models had values intermediate between the 1995 and 1996 models. Species with positive coefficients included Chestnut-collared Longspur (Calcarius ornatus), Baird's Sparrow (Ammodramus bairdii), Grasshopper Sparrow (Ammodramus savannarum), Clay-colored Sparrow (Spizella pallida), American Bittern (Botaurus lentiginosus), Western Meadowlark (Sturnella neglecta), Sedge Wren (Cistothorus platensis), Savannah Sparrow (Passerculus sandwichensis), and American Coot (Fulica americana). Although species appear in the models based on their statistical significance, the breeding-habitat requirements of these species and their associations with habitat types in our analyses further justify their inclusion. Five of the model species (Chestnut-collared Longspur, Baird's Sparrow, Grasshopper Sparrow, Western Meadowlark, and Sedge Wren), including the three with largest positive coefficients, are recognized as grassland-dependent species (Johnson and Igl, 1998). Most model species with positive coefficients breed exclusively in grassland habitats or in wetland habitats associated with grassland. The upland species represented in the models require grassland habitats 
ranging from short- and mixed-grass with low litter accumulation and very few shrubs for Chestnut-collared Longspurs (Renken, 1983; Arnold and Higgins, 1986; Berkey et al., 1993) to relatively dense mixed grass with a high litter accumulation and a component of low shrubs for Clay-colored Sparrows (Renken, 1983; Amold and Higgins, 1986; Knapton, 1994; Madden, 1996). Baird's Sparrows, Grasshopper Sparrows, Savannah Sparrows, and Western Meadowlarks prefer an intermediate grass height with moderate levels of litter (Wiens, 1969, 1973; Kantrud and Kologiski, 1983; Sample, 1989; Johnson and Schwarz, 1993b; Anstey et al., 1995). With the exception of Clay-colored Sparrows and Western Meadowlarks, most of these species have low tolerance for woody vegetation (Faanes, 1983). Though area sensitivity has not been studied in all of these species, Grasshopper Sparrows, Baird's Sparrows, and Savannah Sparrows are known to occur more frequently in relatively large grassland tracts than in small ones (Herkert, 1994; Vickery et al. 1994; Helzer, 1996; Saskatchewan Wetand Conservation Corporation, 1997; Johnson and $\mathrm{lgl}, 2001)$. Sedge Wrens prefer dense vegetation on moist sites, are often found in CRP fields (Sample, 1989; Herkert, 1991; Johnson and Schwartz, 1993a), and appear to prefer larger tracts (Johnson and $\mathrm{Igl}$, 2001). American Bitterns require mid- or tallgrass uplands near emergent marshes $\geq 1$ ha (Kantrud and Higgins, 1992; Baub, 1993). American Coots breed in Prairie Potholes and marshes of all sizes (Stewart, 1975; Daub, 1993).

Species that were negatively correlated to grassland integrity in the index included Horned Larks and Vesper Sparrows. Both species were positively associated with Cropland and negatively associated with Grassland at 200 and $400 \mathrm{~m}$ scales. Although generally considered to be a grassland species, Horned Larks regularly breed in both sparsely vegetated grassland and cropland (DuBois, 1935; Wershler et al, 1991; Patrerson, 1994). Vesper Sparrows are also a grassland species, but are flexible in habitat selection. They are often found in sparse vegetation and cropland (Herkert, 1991; Johnson and Schwartz, 1993a; Camp and Best, 1994).

Species associations with habitat type depend partly on the detectability of the species during the count period. Species are differentially detected depending on the frequency and loudness of their vocalizations, and their relative visibility due both to behavioral and physical traits and to the habitat in which they occur. Models that rely on this method cannot be expected to identify all possible associations of species with habitat type. However, as data from this study and the Breeding Bird Survey (Robbins et al., 1986) indicate, repeated point count data collected by the same observer can provide consistent results over time. Although secretive species that are strongly tied to a given habitat type may be overlooked, relatively easily detected species that are very strongly related to a single habitat type, such as Baird's Sparrow $(n=16)$ and Chestnut-collared Longspur ( $n=70$ ), will likely be represented in the models even if they occur in low numbers.

The presence of many grassland species, combined with the absence of those species associated with woody vegetation, human-made structures, or cropland, can predict a measure of grassland integrity. Identifying regional associations of species with habitat types is labor-intensive, and, because species ranges and habitat types vary widely across the Great Plains, additional models would probably need to be constructed for areas outside the Prairie Pothole Region. This will become increasingly feasible as digital habitat type data become available for a wider geographic area at lower cost. Once models of the type presented here have been constructed, however, they have the advantage of being applied relatively inexpensively to monitor grassland integrity over a large geographic area. We designed our models using 3 min point counts because similar data on breeding bird presence and abundance data are widely available through the North American Breeding Bird Survey. Long-term monitoring of grassland integrity could be achieved using Breeding Bird Survey data, which has been collected annually on hundreds of routes in North America since 1965 (Robbins et al., 1986).

\section{Acknowledgements}

This study was funded in part by the US Environmental Protection Agency (EPA), National Health and Environmental Effects Research Laboratory-Western Ecology Division through an interagency agreement. The manuscript has not been subjected to EPA's peer 
and administrative review process. Mention of trade names or commercial products does not constitute endorsement or recommendation for use. This article was a contribution from the senior author's M.S. thesis at the University of Montana, Missoula, MT. We acknowledge invaluable assistance by Betty R. Euliss, Katherine C. Freshman, Glenn R. Guntenspergen, and H. Thomas Sklebar, and helpful comments by Diane
A. Granfors, Lawrence D. Igl, Thomas E. Martin, and Glen A. Sargeant.

\section{Appendix A}

Common and scientific names of breeding bird species used in the analysis and their habitat groups.

\begin{tabular}{|c|c|}
\hline Common name & Habitat group \\
\hline Pied-billed Grebe (Podilymbus podiceps) & Wetland \\
\hline American Bittern (Botaurus lentiginosus) & Wetland \\
\hline Gadwall (Anas strepera) & Wetland \\
\hline Mallard (Anas platyrhynchos) & Wetland \\
\hline Blue-winged Teal (Anas discors) & Wetland \\
\hline Northern Shoveler (Anas clypeata) & Wetland \\
\hline Northern Pintail (Anas acuta) & Wetland \\
\hline Redhead (Aythya americana) & Wetland \\
\hline Northern Harrier (Circus cyaneus) & Grassland \\
\hline Ferruginous Hawk (Buteo regalis) & Grassland \\
\hline Ring-necked Pheasant (Phasianus colchicus) & Edge \\
\hline Sora (Porzana carolina) & Wetland \\
\hline American Coot (Fulica americana) & Wetland \\
\hline Killdeer (Charadrius vociferus) & Bare-Ground \\
\hline Upland Sandpiper (Bartramia longicauda) & Grassland \\
\hline Marbled Godwit (Limosa fedoa) & Wetland \\
\hline Common Snipe (Gallinago gallinago) & Wetland \\
\hline Black Tern (Chlidonias niger) & Wetland \\
\hline Mourning Dove (Zenaida macroura) & Edge \\
\hline Least Flycatcher (Empidonax minimus) & Woodland \\
\hline Eastern Kingbird (Tyrannus tyrannus) & Edge \\
\hline Western Kingbird (Tyrannus verticalis) & Savanna \\
\hline Warbling Vireo (Vireo gilvus) & Woodland \\
\hline American Crow (Corvus brachyrhynchos) & Edge \\
\hline Horned Lark (Eremophila alpestris) & Bare-Ground \\
\hline Barn Swallow (Hirundo rustica) & Savanna \\
\hline House Wren (Troglodytes aedon) & Edge \\
\hline Sedge Wren (Cistothorus platensis) & Grassland \\
\hline Marsh Wren (Cistothorus palustris) & Wetland \\
\hline American Robin (Turdus migratorius) & Generalist \\
\hline Brown Thrasher (Toxostoma rufum) & Edge \\
\hline Yellow Warbler (Dendroica petechia) & Edge \\
\hline Common Yellowthroat (Geothlypis trichas) & Edge \\
\hline Clay-colored Sparrow (Spizella pallida) & Edge \\
\hline
\end{tabular}

${ }^{1}$ (Stewart, 1975; Ehdich et al., 1988; Feterohn and Sauer, 1993). 
Appendix A. (Continued)

Common name

Habitat group

Vesper Sparrow (Pooecetes gramineus)

Grassland

Savannah Sparrow (Passerculus sandwichensis)

Grassland

Grasshopper Sparrow (Ammodramus savannarum)

Grassland

Baird's Sparrow (Ammodramus bairdii)

Le Conte's Sparrow (Ammodramus leconteii)

Nelson's Sharp-tailed Sparrow (Ammodramus nelsoni)

Song Sparrow (Melospiza melodia)

Chestnut-collared Longspur (Calcarius ornatus)

Bobolink (Dolichonyx oryzivorus)

Red-winged Blackbird (Agelaius phoeniceus)

Grassland

Western Meadowlark (Sturnella neglecta)

Yellow-headed Blackbird (Xanthocephalus xanthocephalus)

Wetland

Common Grackle (Quiscalus quiscula)

Wetland

Brown-headed Cowbird (Molothrus ater)

Edge

Grassland

American Goldfinch (Cardeulis tristis)

Grassland

Wetland

Grassland

Wetland

House Sparrow (Passer domesticus)

Edge

Edge

Edge

Generalist

\section{References}

Anstey, D.A., Davis, S.K., Duncan, D.C., Skeel, M., 1995 Distribution and Habitat Requirements of Eight Grassland Songbird Species in Southern Saskatchewan. Saskatchewan Wetland Conservation Corporation, Regina, Saskatchewan, Canada, p. 11.

Arnold, T.W., Higgins, K.F., 1986. Effects of shrub coverages on birds of North Dakota mixed-grass Prairies. Can. Field Nat. 100, 10-14.

Baer, N.W., 1989. Shelterbelts and windbreaks in the Great Plains. J. For. $87,32-36$.

Berkey, G., Crawford, R., Galipeau, S., Johnson, D., Lambeth. D., Kreil, R., 1993. A review of wildlife management practices in North Dakota: effects on nongame bird populations and habitats. Unpublished report submitted to Region 6. US Fish and Wildlife Service, Denver, Colorado, USA. p. 51.

Berkman, H.E., Rabeni, C.F., Boyle, T.P., 1986. Bio-monitors of stream quality in agricultural areas: fish vs. invertebrates. Environ. Manage. 10, 413-419.

Blair, R.B., Launer, A.E., 1997. Butterfly diversity and human land use: species assemblages along an urban gradient. Biol. Conserv. 80, 113-125.

Bollinger, E.K., Gavin, T.A., 1992. Eastern Bobolink populations: ecology and conservation in an agricultural landscape. In: Hagan III, J.M., Johnston, D.W. (Eds.), Ecology and Conservation of Neotropical Migrant Landbirds. Smithsonian Institution Press, Washington, DC, USA, pp. 497-506

Bradford, D.F., Franson, S.E., Neale, A.C., Heggem, D.T., Miller, G.R., Canterbury, G.E., 1998. Bird species assemblages as indicators of biological integrity in Great Basin rangeland. Environ. Monitor. Assess. 49, 1-22.
Browder, S.F., 1998. Assemblages of grassland birds as indicators of environmental condition. M.S. Thesis, University of Montana, Missoula, Montana, USA, p. 82

Camp, M., Best, L.B., 1994. Nest density and nesting success of birds in roadsides adjacent to rowcrop fields. Am. Midland Nat. 131, 347-358.

Canterbury, G.E., Martin, T.E., Petit, D.R., Petit, L.J., Bradford, D.F., 2000. Bird communities and habitat as ecological indicators of forest condition in regional monitoring. Conserv. Biol. 14, 544-558.

Cowardin, L.M., Carter, V., Golet, F.C., LaRoe, T.E., 1979. Classification of wetlands and deepwater habitats of the United States. US Department of the Interior, Fish and Wildlife Service, Washington, DC, USA.

Croonquist, M.J., Brooks, R.P., 1991. Use of avian and mammalian guilds as indicators of cumulative impacts in riparian-wetland areas. Environ. Manage. 15, 701-714.

Dahl, T.E., Johnson, C.E., Frayer, W.E., 1991. Status and Trends of Wetlands in the Conterminous United States, mid-1970s to mid-1980s. US Department of the Interior, Fish and Wildlife Service, Washington, DC, USA, p. 28.

Daub, B.C., 1993. Effects of marsh area and characteristics on avian diversity and nesting success. M.S. Thesis, University of Michigan, Michigan, USA, p. 37.

Droege, S., Sauer, J.R., 1994. Are more North American species decreasing than increasing? In: Hagemeijer, E.J.M., Verstrael, T.J. (Eds.), Proceedings 12th International Conference of IBCC and EOAC, Noordjwijkerhout on Bird Numbers 1992. Distribution, Monitoring and Ecological Aspects. The Netherlands, Statistics Netherlands, Voorburg/Heerlen and SOVON, Beek-Ubbergen, pp. 297-306. 
DuBois, A.D., 1935. Nests of Horned Larks and longspurs on a Montana Prairie. Condor 37, 56-72.

Ehrlich, P.R., Dobkin, D.S., Wheye, D., 1988. The Birder's Handbook: a Field Guide to the Natural History of North American Birds. Simon and Schuster Inc., New York, USA, p. 785 .

Faanes, C., 1983. Breeding birds of wooded draws in western North Dakota. Prairie Nat. 15, 173-187.

Helzer, C.J., 1996. The effects of wet meadow fragmentation on grassland birds. M.S. Thesis, University of Nebraska, Lincoln, Nebraska, USA, p. 65.

Herkert, J.R., 1991. An ecological study of the breeding birds of grassland habitats within Illinois. Ph.D. Thesis, University of Illinois, Urbana, Illinois, USA, p. 115.

Herkert, J.R., 1994. The effects of habitat fragmentation on midwestern grassland bird communities. Ecol. Appl. 4, 561571.

Igl, L.D., Johnson, D.H., 1997. Changes in breeding bird populations in North Dakota: 1967 to 1992-93. Auk 114, 74-92.

Igl, L.D., Johnson, D.H., 1999. Le Conte's Sparrows breeding in Conservation Reserve Program fields: precipitation and patterns of population change. In: Vickery, P.D., Herkert, J.R. (Eds.), Ecology and Conservation of Grassland Birds of the Western Hemisphere. Studies in Avian Biology 19, pp. 178-186.

Johnson, D.H., 1996. Management of northern Prairies and wetlands for the conservation of Neotropical migratory birds. In: Thompson III, F.R. (Ed.), US Department of Agriculture, Forest Service, General Technical Report NC-187, pp. 53-67.

Johnson, D.H., Igl, L.D., 1998. Effects of management practices on grassland birds. Northern Prairie Wildlife Research Center, Jamestown, North Dakota, USA, http:/Www npwrcusgs gov.

Johnson, D.H., Igl, L.D., 2001. Area requirements of grassland birds: a regional perspective. Auk 118, 24-34.

Johnson, D.H., Schwartz, M.D., 1993a. The conservation reserve program and grassland birds. Conserv. Biol. 7, 934-937.

Johnson, D.H., Schwartz, M.D., 1993b. The conservation reserve program: habitat for grassland birds. Great Plains Res. 3, 273295.

Johnson, R.G., Temple, S.A., 1990. Nest predation and brood parasitism of tallgrass Prairie birds. J. Wildlife Manage. 54, 106-111.

Kantrud, H.A., 1981. Grazing intensity effects on the breeding avifauna of North Dakota native grasslands. Can. Field Nat. 95, 404-417.

Kantrud, H.A., 1996. Plants as indicators of wetland condition in the Prairie Pothole Region. In: Peterson, S.A., Carpenter, L., Guntenspregen, G., Cowardin, L.M. (Eds.), Pilot Test of Wetland Condition Indicators in the Prairie Pothole Region of the United States. US Environmental Protection Agency, Corvallis, Oregon, USA, pp. 71-118.

Kantrud, H.A., Higgins, K.F., 1992. Nest and nest site characteristics of some ground-nesting, non-passerine birds of northern grasslands. Prairie Nat. 24, 67-84.

Kantrud, H.A., Kologiski, R.L., 1983. Avian associations of the northern Great Plains grasslands. J. Biogeogr. 10, 331-350.

Karr, J.R., 1981. Assessment of biotic integrity using fish communities. Fisheries 6, 21-27.
Karr, J.R., 1991. Biological integrity: a long-neglected aspect of water resource management. Ecol. Appl. 1, 66-84.

Karr, J.R., Fausch, K.D., Angermeier, P.L., Yant, P.R., Schlosser, I.J., 1986. Assessing biological integrity in running waters: a method and its rationale. Illinois Nat. History Surv. 5, 28.

Knapton, R.W., 1994. Clay-colored Sparrow (Spizella pallida). In: Poole, A., Gill, F. (Eds.), The Birds of North America, No. 120. The Academy of Natural Sciences, Philadelphia, Pennsylvania, The American Ornithologists' Union, Washington, DC, USA, p. 16.

Knopf, F.L., 1994. Avian assemblages on altered grasslands. Stud. Avian Biol. 15, 247-257.

Kremen, C., 1992. Assessing the indicator properties of species assemblages for natural areas monitoring. Ecol. Appl. 2, 203217.

Larson, D.L., 1996. Pesticides in wetland sediments as indicators of environmental stress. In: Peterson, S.A., Carpenter, L., Guntenspergen, G., Cowardin, L.M. (Eds.), Pilot Test of Wetland Condition Indicators in the Prairie Pothole Region of the United States. US Environmental Protection Agency, Corvallis, Oregon, USA, pp. 145-148.

Lenat, D.R., 1988. Water quality assessment of streams using a qualitative collection method for benthic macroinvertebrates. J. N. Am. Benthol. Soc. 7, 222-233.

Madden, E.M., 1996. Passerine communities and bird-habitat relationships on prescribe-burned, mixed-grass Prairie in North Dakota. M.S. Thesis, Montana State University, Bozeman, Montana, USA, p. 153.

Martin, T.E., 1980. Diversity and abundance of spring migratory birds using habitat islands on the Great Plains. Condor 82, 430-439.

Martin, T.E., Vohs, P.A., 1978. Configuration of shelterbelts for optimum utilization by birds, In: Tinus, R.W. (Ed.), Proceedings of the 30th Annual Forestry Commission Great Plains Agricultural Council. Great Plains Agricultural Council Publication No. 87, Tulsa, Oklahoma, USA, pp. 79-88.

MicroImages, 1996. TNTMIPS Version 5.5. MicroImages Inc. Lincoln, Nebraska, USA.

Norusis, M.J., 1995. SPSS 6.1 Guide to Data Analysis. Prentice Hall, Englewood Cliffs, NJ, USA, p. 582.

Noss, R.F., 1990. Indicators for monitoring biodiversity: a hierarchical approach. Conserv. Biol. 4, 355-364.

Noss, R.F., LaRoe III, E.T., Scott, J.M., 1995. Endangered ecosystems of the United States: a preliminary assessment of loss and degredation. Biological Report 28. National Biological Service, Washington, DC, USA, p. 58.

Ohio Environmental Protection Agency, 1988. Biological criteria for the protection of aquatic life. Division of Water Quality Monitoring and Assessment, Surface Water Section, Columbus, Ohio, USA.

O'Leary, C.H., 2000. Treelines between fields reduce the density of grassland birds. Nat. Areas J. 20, 243.

Patterson, M.P., 1994. Bird species abundance, composition, and vegetation characteristics, and bird productivity in Conservation Reserve Program land in central Iowa. M.S. Thesis, Iowa State University, Ames, Iowa, USA, p. 54.

Peterjohn, B.G., Sauer, J.R., 1993. North American Breeding Bird Survey annual summary, 1990-1991. Bird Popul. 1, 52-67. 
Plafkin, J.L., Barbour, M.T., Porter, K.D., Gross, S.K., Hughes, R.M., 1989. Rapid bioassessment protocols for use in streams and rivers: benthic macroinvertebrates and fish. US Environmental Protection Agency, Washington, DC, USA, EPA/444/4-89-001.

Price, J., Droege, S., Price, A., 1995. The Summer Atlas of North American birds. Academic Press Inc. Harcourt Brace and Company, London, p. 364.

Renken, R.B., 1983. Breeding bird communities and bird-habitat associations on North Dakota waterfowl production areas of three habitat types. M.S. Thesis, Iowa State University, Ames, Iowa, USA, p. 90.

Robbins, C.S., Bystrak, D., Geissler, P.H., 1986. The Breeding Bird Survey: its first fifteen years, 1965-1979. US Fish and Wildlife Service, Resource Publication 157, p. 196.

Sample, D.W., 1989. Grassland birds in southern Wisconsin: habitat preference, population trends, and response to land use changes. M.S. Thesis, University of Wisconsin, Madison, Wisconsin, US, p. 588.

Samson, F., Knopf, F., 1994. Prairie conservation in North America. BioScience 44, 418-421.

Saskatchewan Wetland Conservation Corporation, 1997. Grassland Bird Conservation Through Saskatchewan's Native Prairie Stewardship Program. Regina, Saskatchewan, Canada, p. 25.

Stewart, R.E., 1975. Breeding birds of North Dakota. Tri-College Center for Environmental Studies, Fargo, North Dakota, USA, p. 295.

Szaro, R.C., 1986. Guild management: an evaluation of avian guilds as a predictive tool. Environ. Manage. 10, 681-688.

US Environmental Protection Agency, 1993. Draft program guide: environmental monitoring and assessment program. Office of Research and Development, Cincinnati, Ohio, USA, p. 35.
US Department of Commerce, 1994. 1992 Census of Agriculture, vol. 1, Part 34. North Dakota, AC92-A-34. Bureau of the Census, Washington, DC, USA, p. 399.

US Department of Agriculture, 1997. National Range and Pasture Handbook. Natural Resources Conservation Services. Grazing Lands Technology Institute, 190-vi-NRPH, p. 472.

Vickery, P.D., Hunter Jr., M.L., Melvin, S.M., 1994. Effects of habitat area on the distribution of grassland birds in Maine. Conserv. Biol. 8, 1087-1097.

Vickery, P.D., Tubaro, P.L., da Silva, J.M.C., Peterjohn, B.G., Herkert, J.R., Cavalcanti, R.B., 1999. Conservation of grassland birds in the Western Hemisphere. In: Vickery, P.D., Herkert, J.R. (Eds.), Ecology and Conservation of Grassland Birds in the Western Hemisphere. Studies in Avian Biology 19 , pp. 2-26.

Wiens, J.A., 1969. An approach to the study of ecological relationships among grassland birds. Ornithol. Monogr. 8, 93.

Wiens, J.A., 1973. Interterritorial habitat variation in Grasshopper and Savannah Sparrows. Ecology 54, 877-884.

Wershler, C., Smith, W.W., Wallis, C., 1991. Status of the Baird's Sparrow in Alberta: $1987 / 1988$ update with notes on other grassland sparrows and Sprague's Pipit. In: Holroyd, G.L., Burns, G., Smith, H.C. (Eds.), Proceedings of the Second Endangered Species and Prairie Conservation Workshop. Natural History Occasional Paper No. 15. Provincial Museum of Alberta, Edmonton, Alberta, Canada, pp. 87-89.

Winter, M., Johnson, D.H., Faaborg, J., 2000. Evidence for edge effects on multiple levels in tallgrass Prairie. Condor 102, 256266. 